\title{
Clas Hermansson in memoriam
}

\author{
Clas Hermansson till minne
}

\author{
Lotta Berg'1 (iD) \& Åke Abrahamsson² \\ Hornborgasjöns fältstation, Hornborgasjön, 52198 Broddetorp, Sweden \\ ${ }^{1}$ lotta.berg@birdlife.se ${ }^{2}$ ake.p.abrahamsson@telia.com
}

CLAS HERMANSSON is one of the co-authors of a paper in this volume of Ornis Svecica (Nilsson \& Hermansson 2021), one of many articles that he has written in different ornithological journals over the years. However, as the first Common Cranes Grus grus arrived at Lake Hornborgasjön this spring on their migratory journey back from their winter quarters, the sad news reached us: Clas Hermansson had passed away at the age of 73 after a period of illness.

The Common Cranes at Lake Hornborgasjön were one of Clas' favourite interests. During decades he, together with Alf Karlsson, was responsible for the counting of the cranes in the spring and during the autumn. Over the years, large amounts of data were collected on his initiative. This did not only cover the cranes at their stop-over at Lake Hornborgasjön, but also general knowledge about the behaviour and habits of this species. His interests, however, were wider than this and also covered the cranes from an international perspective, including an engagement in the recurring European Crane Working Group conferences. Some years ago, his knowledge about our cranes resulted in a beautiful book about the cranes at Lake Hornbor- gasjön, published by the Lake Hornborgasjön Bird Observatory (Hermansson \& Karlsson 2013), which rapidly sold out.

Clas was raised in the region of Västergötland and initially active in the birding club in Skövde, and one of the initiators and editors of GRUS, presently the member magazine of Västergötlands ornitologiska förening. He was engaged in the restoration of Lake Hornborgasjön in the 1990s, and did-together with a number of other enthusiasts-form the Lake Hornborgasjön Bird Observatory in 1983 . The bird observatory continues to this day to organise bird census efforts, bird ringing, and other biological surveys to document the development of the lake. Clas had valuable contacts within the research community, related to cranes and waterfowl, and especially within the field of goose population management.

In addition to this, Clas organised and implemented important bird census projects also in other parts of the country, especially on the island of Gotland in the Baltic Sea, where he settled in recent years. He maintained his commitment for the cranes and their breeding and migration patterns, and further added anything from surveys of overwintering Common Blackbirds Turdus merula to 


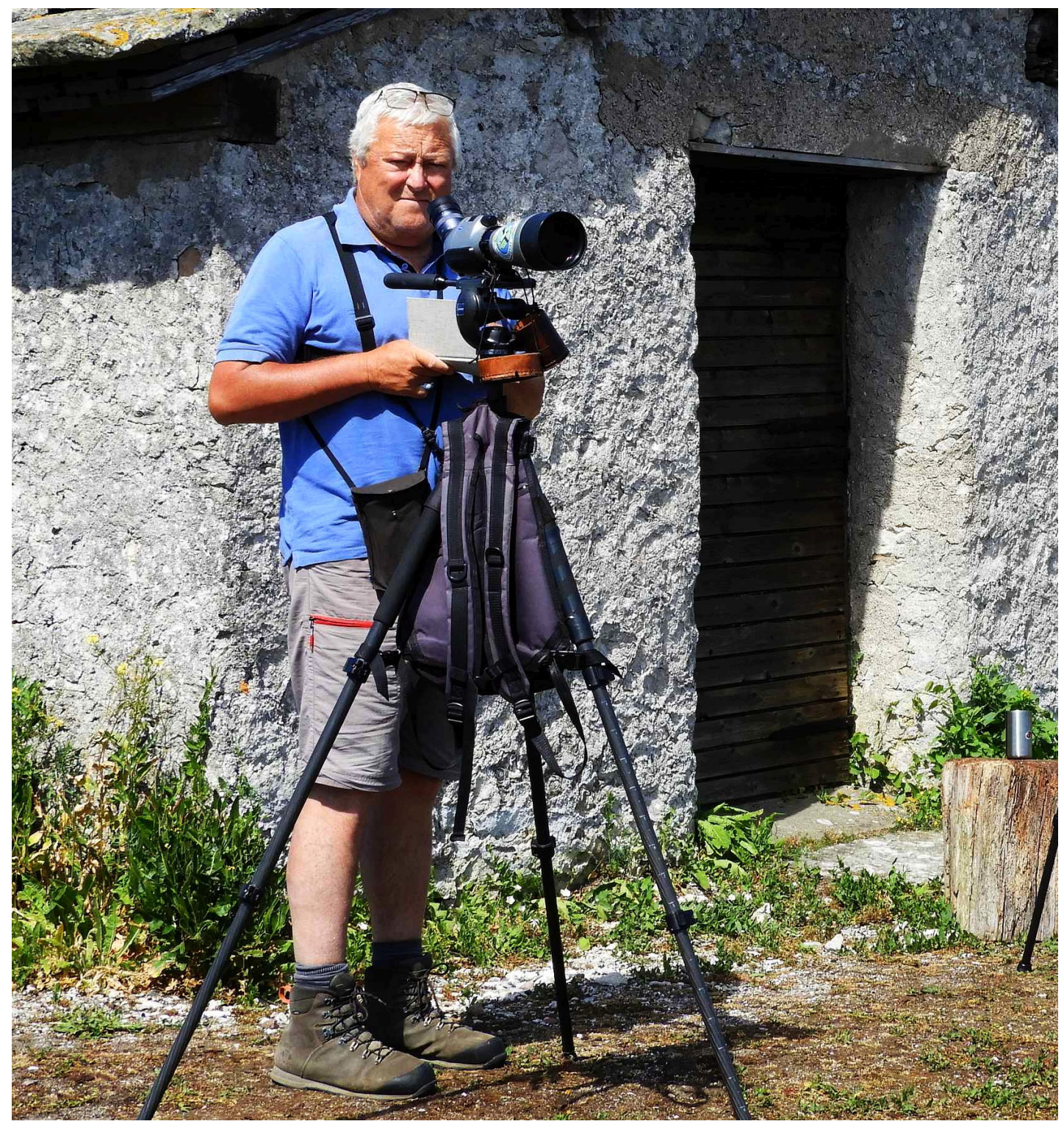

Clas Hermansson watching migrating terns and waterfowl, Faludden, Gotland, 2019. Photo: Lotta Berg. Clas Hermansson spanar efter sträckande tärnor och sjöfåglar, Faludden, Gotland, 2019. Foto: Lotta Berg.

seabird counts and censusing of nocturnal birds. He was particularly active regarding the avifauna of the island Stora Karlsö, a magnificent bird island in the Baltic Sea.

In 2009, Clas was awarded BirdLife Sweden's research award for his efforts within Swedish ornithology. Clas was a very knowledgeable, meticulous, persistent, and kind birder, and we will miss him immensely.

\section{References}

Hermansson C \& Karlsson A. 2013. Tranorna vid Hornborgasjön. Hornborgasjöns fältstation, Broddetorp. 96 pp.

Nilsson L \& Hermansson C. 2021. Changes in numbers and distribution of wintering waterbirds around Gotland 1969-2020. Ornis Svecica 31: 78-93. https://doi.org/10.34080/os.v31.22254 


\section{Svensk version}

Clas Hermansson är medförfattare till en av artiklarna i denna årgång av Ornis Svecica (Nilsson \& Hermansson 2021), en av många artiklar som han skrivit i olika ornitologiska tidskrifter genom åren. Men när vårens första tranor Grus grus i år anlände till Hornborgasjön nåddes vi av sorgebudet att Clas Hermansson efter en tids sjukdom har gått bort vid en ålder av 73 år. Tranorna vid Hornborgasjön var ett av Clas riktigt stora intressen. Under många årtionden svarade han för tranräkningarna vår och höst tillsammans med Alf Karlsson. Mängder med värdefulla data har genom Clas försorg samlats in genom åren. Då handlar det inte endast om de rastande tranorna utan om arten i vidaste bemärkelse. Engagemanget var emellertid bredare än så och omfattade även internationella tranfrågor, inte minst genom Clas engagemang i de återkommande europeiska trankonferenserna. Clas kunskaper om våra tranor resulterade för några år sedan i en mycket vacker bok om tranorna vid Hornborgasjön, som gavs ut av Hornborgasjöns fältstation (Hermansson \& Karlsson 2013) och snabbt såldes slut.

Clas var västgöte och därför länge aktiv i Skövde fågelklubb och en av initiativtagarna till tidskriften GRUS samt även dess redaktör fram till att den efter ett tiotal år togs över av den nybildade Skaraborgs läns ornitologiska förening med ny redaktör. Clas engagerade sig i arbetet inför Hornborgasjöns restaurering på 9o-talet, och bildade tillsammans med andra entusiaster Hornborgasjöns fältstation som organiserade fågelinventeringar, ringmärkning och andra biologiska undersökningar som skulle dokumentera sjöns utveckling. Clas knöt värdefulla kontakter inom forskarvärlden, vad gäller tranor, simfåglar och inte minst inom området som handlar om förvaltning av stora gåspopulationer.

Utöver detta hann Clas med att organisera och genomföra viktiga ornitologiska inventeringsprojekt även i andra delar av landet - inte minst på Gotland där han bosatte sig på senare år. Där fortsatte han att engagera sig i tranorna och deras häcknings- och flyttvanor, och därtill i allt från koltrastinventeringar till sjöfågelräkningar och nattfågelinventeringar. Han var mycket aktiv vad gäller fågelfaunan på Stora Karlsö, denna fantastiska fågelklippa i Östersjön.

År 2009 tilldelades Clas Hermansson BirdLife Sveriges amatörforskningspris för sin gärning inom svensk ornitologi. Clas var en mycket kunnig, noggrann, envis och vänlig fågelskådare, och vi kommer att sakna honom mycket.

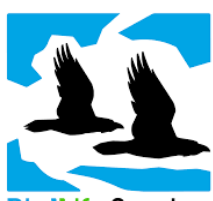

Birdlife Sverige

Ornis Svecica (ISSN 2003-2633) is an open access, peer-reviewed scientific journal published in English and Swedish by BirdLife Sweden. It covers all aspects of ornithology, and welcomes contributions from scientists as well as non-professional ornithologists. Accepted articles are published at no charge to the authors. Read papers or make a submission at os.birdlife.se.

Ornis Svecica (ISSN 2003-2633) är en fritt tillgänglig granskad vetenskaplig tidskrift som ges ut på svenska och engelska av BirdLife Sverige. Den täcker ornitologins alla områden och välkomnar bidrag från såväl forskare som icke-professionella ornitologer. Accepterade uppsatser publiceras utan kostnad för författarna. Läs uppsatser eller skicka in ditt bidrag på os.birdlife.se. 